CIVICS EDUCATION AND SOCIAL SCIENSE JOURNAL(CESSJ)

Volume 1 Nomor 2 Bulan Desember 2019

\title{
AKTUALISASI NILAI KEADILAN SOSIAL DALAM PANCASILA MELALUI KONSEP TA'A WUN GERAKAN MUHAMMADIYAH
}

(Studi Kasus di Lembaga Zakat dan Amal Lazismu Kota Surakarta)

\author{
Dr. Ahmad Muhibbin, M.Si dan Albi Arangga \\ Fakultas Keguruan dan Ilmu Pendidikan \\ Universitas Muhammadiyah Surakarta
}

\begin{abstract}
ABSTRAK
Penelitian ini bertujuan untuk mengetahui bagaimana wujud aktualisasi nilai keadilan sosial pada Pancasila melalui konsep ta'awun gerakan Muhammadiyah. Jenis penelitian ini adalah kualititatif dengan desain studi kasus yang dalam arti difokuskan pada suatu fenomena tertentu yang akan dipahami secara komprehensif. Penelitian ini dilakukan di Lembaga Zakat dan Amal Lazismu Kota Surakarta.

Pengumpulan data dalam penelitian ini menggunakan metode observasi, wawancara, dan dokumentasi. Validitas data yang digunakan adalah dengan model triangulasi data yang dihasilkan dari ketiga motede penelitian kualitatif. Analisis data yang digunakan dalam penelitian ini adalah model interaktif yang seluruh prosesnya melalui tahap pengumpulan, reduksi, penyajian dan verifikasi data. Hasil penelitian menunjukan bahwa terdapat wujud aktualisasi nilai keadilan sosial dalam Pancasila melalui konsep ta'awun Muhammadiyah, yang telah dilaksanakan oleh Lazismu Kota Surakarta. Pengaktuliasian nilai keadilan sosial dalam Pancasila diwujudkan dengan adanya agenda-agenda filantropis dan pemberdayaan sosial yang dilaksanakan oleh Lazismu Kota Surakarta.
\end{abstract}

Kata Kunci: Aktualisasi, Keadilan Sosial, Konsep Ta'awun Muhammadiyah

JORNAL PROGDI PPKn, FKIP UNIVET BANTARA SUKOHARJO BEKERJA SAMA DENGAN ASSOSIASI PROFESI PENDIDIKAN PANCASILA DAN KEWARGANEGARAAN (AP3KNI) JAWA TENGAH 
CIVICS EDUCATION AND SOCIAL SCIENSE JOURNAL(CESSJ)

Volume 1 Nomor 2 Bulan Desember 2019

\section{ABSTRACT}

This study aims to find out how to actualize the value of social justice in Pancasila through the concept of ta'awun Muhammadiyah movement. This type of research is qualitative with a case study design which in the sense is focused on a particular phenomenon that will be comprehensively understood. This research was conducted at the Lazismu Charity and Zakat Institution in Surakarta. Data collection in this study uses the method of observation, interviews, and documentation.

The validity of the data used is the triangulation model of data generated from the three qualitative research motives. Data analysis used in this study is an interactive model whose entire process goes through the stages of data collection, reduction, presentation and verification. The results showed that there was a form of actualizing the value of social justice in Pancasila through the concept of Muhammadiyah ta'awun, which had been implemented by Lazismu in Surakarta. The actualization of the value of social justice in Pancasila is realized with the philanthropic and social empowerment agendas implemented by Lazismu Surakarta.

Keywords: Actualization, Social Justice, Muhammadiyah Ta'awun Concept

\section{PENDAHULUAN}

Negara Indonesia didirikan oleh para founding fathers didasarkan atas konsep filosofis-empiris bangsa. Latar belakang atas konsep tersebut merupakan refleksi dari fakta sejarah kolonialisme yang pernah terjadi pada bangsa Indonesia. Tindakan penindasan dan segala perilaku kesewenang-wenangan yang dilakukan oleh para penjajah telah menciptakan penderitaan bagi bangsa Indonesia dalam kurun waktu yang sangat lama (Latif, 2015: 4).

Keresahan yang lahir atas penderitaan bangsa menjadi momentum strategis untuk merebut dan memperjuangkan kemerdekaan bagi Bangsa Indonesia. Kesadaran kolektif tersebut mengimplikasikan adanya semangat persatuan dan kesatuan bangsa dari segala perbedaan suku, ras, agama, dan adat yang beranekaragam. Realitas tersebut menurut Koento sebagaimana dikutip Lanur (1995: 125) telah menjadikan dasar filsafat Negara Indonesia, yakni Pancasila sebagai manifestasi dari unsur nilai-nilai yang telah tumbuh dan berkembang secara dinamis.

Pancasila sebagai falsafah negara digali dari nilai-nilai leluhur bangsa yang di dalamnya meliputi nilai agama, nilai sosial budaya, serta nilai perjuaangan yang telah mengakar di tengah kehidupan masyarakat dan bangsa Indonesia. Manifestasi tersebut kemudian dirumuskan secara ideologis dan mengkristal menjadi lima sila 
CIVICS EDUCATION AND SOCIAL SCIENSE JOURNAL(CESSJ)

Volume 1 Nomor 2 Bulan Desember 2019

yang saling berkaitan. Kelima sila dalam Pancasila tersebut dijadikan rujukan sumber dari segala sumber yang bersifat Yuridis pada Pembukaan UUD 1945 sebagai dasar negara Indonesia (Roza et al., 2016: 3).

Pancasila memiliki beberapa nilai yang terkandung di dalamnya. Nilai-nilai tersebut meliputi Nilai Ketuhanan, Nilai Kemanusiaan, Nilai Persatuan, Nilai Kerakyatan dan Nilai Keadilan Sosial, yang merupakan pengejawantahan dari lima sila. Kelima nilai tersebut adalah hasil ide, gagasan, pemikiran, serta penilaian falsafah bangsa Indoensia. Nilai-nilai yang terdapat pada Pancasila sudah semestinya menjadi acuan norma, etika, moral, dan budaya dalam kehidupan berbangsa dan bernegara (Latif, 2015:42).

Pancasila merupakan dasar pijakan bangsa Indonesia dalam memahami dan cara-cara hidup yang dapat dijadikan sebagai pedoman manusiawi bagi hidup bersama di Indonesia. Hal relevan yang dapat digali pada nilai falsafah Pancasila secara komprehensif terletak pada cara pengaktualisasian nilai-nilai Pancasila dalam kehidupan sosial-masyarakat. Pengembangan nilai-nilai Pancasila dalam sosial-masyarakat perlu diperkuat melalui doktrinasi ideologis serta tindakan konkret sebagai wujud pengamalan nilai-nilai Pancasila, sehingga Pancasila tetap konsisten sebagai wacana kehidupan masyarakat.

Salah satu nilai-nilai pada Pancasila yang dapat dikembangkan dan diaktualisasikan secara masif dalam kehidupan bangsa ialah nilai keadilan sosial sebagai suatu akumulasi dari sila kelima Pancasila. Makna nilai keadilan sosial yang terkandung dalam Pancasila menurut Yudhistira (2016) ialah mengakui dan memperlakukan manusia sesuai dengan harkat dan martabatnya sebagai makhluk Tuhan, mengakui persamaan derajad, persamaan hak dan kewajiban asasi setiap manusia tanpa membeda-bedakan suku, keturunan, agama, kepercayaan, jenis kelamin, kedudukan sosial, hingga ras, mengembangkan sikap saling mencintai sesama manusia, mengembangkan sikap saling tenggang rasa dan tepa selira, menumbuhkan sikap tidak semena-mena terhadap orang lain, menjunjung tinggi nilai-nilai keadilan sosial, masifikasi dalam melakukan kegiatan keadilan sosial, serta menegakkan kebenaran dan keadilan.

Atas dasar negara yang telah dirumuskan secara filosofis mengenai hakikat keadilan sosial yang bersifat abstrak sebagai nilai dasar, maka penjabaran nilai keadilan sosial dalam Pancasila perlu dikontekskan pada suatu tatanan sosial yang bersifat dinamis pada era dewasa saat ini sebagai nilai instrumental. Perilaku dan keseharian masyarakat menjadi tolak ukur sejauh mana nilai keadilan sosial pada 
CIVICS EDUCATION AND SOCIAL SCIENSE JOURNAL(CESSJ)

Volume 1 Nomor 2 Bulan Desember 2019

Pancasila dapat berkembang, lalu diterapkan dan diaktualisasikan ke dalam suatu tatanan realitas sosial-masyarakat sebagai nilai praksis (Yudhistira, 2016).

Aktualisasi nilai keadilan sosial Pancasila dalam rangka pelaksanaan praksis dapat diwujudkan dalam realisasi gerakan sosial-masyarakat. Perwujudan tersebut dapat ditinjau dari pola gerakan dakwah Muhammadiyah sebagai organisasi gerakan civil society muslim di Indonesia. Gerakan dakwah Muhammadiyah didasarkan atas tindakan konkret, yakni mengamalkan nilai ajaran Islam yang bersumber pada Al-Quran dan As-Sunnah

Persyarikatan Muhammadiyah yang didirikan Ahmad Dahlan merupakan gerakan Islam yang membawa misi dakwah dan tajdid yang menjawab permasalahan-permasalahan sosial dan ketidakadilan (Nashir dkk, 2019). Menurut Nahsir (2016), bahwa gerakan Muhammadiyah senantiasa melakukan langkahlangkah pembaharuan atau modernisasi di bidang pemahaman dan pembinaan keagamaan, kesehatan, pelayanan sosial, dalam amal usaha yang terus berkembang, yang semuanya merupakan basis pandangan Islam berkemajuan. Pola modernisasi yang dijadikan sebagai standar prinsip gerakan Muhammadiyah dapat dipandang sebagai wujud konformisasi yang menurut Jun (2014) merupakan suatu ide yang menganggap moralitas, agama, dan masyarakat berasal dari prinsip tertentu, yang dalam konteks ini bagi Muhammadiyah adalah Islam. Hal inilah yang mendasari bahwa kebanyakan dari organisasi Islam lebih menekankan pada dakwah dan pendidikan sosial dari pada gerakan politik (Viartasiwi, 2013), yang salah satunya adalah Muhammadiyah.

Pada Milad Muhammadiyah yang ke-106 tahun 2018 lalu, Muhammadiyah mengusung konsep Ta'awun untuk Negeri. Konsep ta'awun menurut Mu'ti (2018) merupakan sebuah ide gerakan Muhammadiyah yang memperkuat basis komitmen, tanggungjawab, serta jati diri Muhammadiyah sebagai gerakan Islam, keadilan sosial, dan keindonesiaan. Penjelmaan atas konsep ta'awun merupakan pemikiran terdahulu oleh Kyai Haji Ahmad Dahlan selaku pendiri organisasi Muhmmadiyah tentang perjuangan dakwah Nabi Muhammad SAW dalam mengembangkan tata kehidupan masyarakat sebagaimana yang telah dikehendaki Islam, yakni berkarya dan berbuat sesuatu dalam rangka menciptakan kebaikan.

Tindakan konkret yang dilakukan oleh Muhammadiyah menunjukkan adanya indikasi pelaksanaan praksis nilai keadilan sosial pada Pancasila. Hal tersebut dibuktikkan dengan kualitas gerakan Muhammadiyah yang mengedepankan kepentingan umum dalam rangka mewujudkan kebaikkan antar sesama manusia. Berdasarkan latar belakang masalah yang telah dinarasikan di atas, maka dipandang 
CIVICS EDUCATION AND SOCIAL SCIENSE JOURNAL(CESSJ)

Volume 1 Nomor 2 Bulan Desember 2019

cukup penting untuk melakukan penelitian tentang "Aktualisasi Nilai Keadilan sosial dalam Pancasila melalui Konsep Ta'awun Persyarikatan Muhammadiyah,” dengan studi kasus di Lembaga Zakat dan Amal Lazismu Kota Surakarta.

\section{METODE}

Metode penelitian ini adalah deskriptif kualitatif. Pengumpulan data dalam penelitian ini menggunakan metode observasi, wawancara, dan dokumentasi. Validitas data yang digunakan adalah dengan model triangulasi data yang dihasilkan dari ketiga motede pengumpulan data kualitatif. Analisis data yang digunakan dalam penelitian ini adalah model interaktif yang seluruh prosesnya melalui tahap pengumpulan, reduksi, penyajian dan verifikasi data.

\section{HASIL PENELITIAN DAN PEMBAHASAN}

Falsafah Pancasila dalam konteks mewujudkan keadilan adalah bangunan kesadaran sosiologis yang dibutuhkan bagi bangsa Indonesia. Sejarah bangsa Indonesia yang kelam merupakan realitas empirik yang memunculkan sisi kognitif dan afektif masyarakat dalam mengupayakan negara yang adil dan sejahtera. Hal tersebut merupakan porses epistemologi filsafat Pancasila yang mengindikasikan adanya urgensi tentang wacana keadilan sosial dalam kehidupan berbangsa dan bernegara (Latif, 2018).

Implementasi nilai keadilan sosial dalam Pancasila memerlukan kesadaran aktif dalam menjadikannya sebagai pandangan dan pedoman hidup bangsa. Manifestasi atas kesadaran aktif bangsa dapat diwujudkan dalam bentuk aktualisasi yang memerlukan penguatan internal sebagai bagian dari kepercayaan moral bangsa terhadap keyakinan nilai keadilan yang terkandung dalam Pancasila. Aktualisasi tersebut merupakan suatu proses progressif yang berangsur secara bertahap dalam upaya "menjadi", walaupun berbagai unsur permanensi realitas dan identitas diri dalam perubahan tidak dapat diabaikan (Soeprapto, 1995).

Berdasarkan pemaparan di atas, maka penelitian ini membahas mengenai wujud dari aktualisasi nilai keadilan sosial dalam Pancasila melalui konsep ta'awun gerakan Muhammadiyah, yang telah dilakukan oleh Laszismu Kota Surakarta. Wujud dari pengaktualisasian nilai keadilan sosial dalam Pancasila tersebut dilakukan melalui berbagai agenda-agenda filantropi dan pemberdayaan sosial yang telah dilaksanakan oleh Lazismu Kota Surakarta. Pembahasan ini disusun berdasarkan hasil dari proses observasi, wawancara, dan dokumentasi yang telah dilakukan oleh peneliti. 
CIVICS EDUCATION AND SOCIAL SCIENSE JOURNAL(CESSJ)

Volume 1 Nomor 2 Bulan Desember 2019

\section{Menumbuhkan Sikap Kekeluargaan dan Persahabatan}

Salah satu indikator dalam mengaktualisasikan nilai keadilan sosial dalam Pancasila adalah menumbuhkan sikap kekeluargaan dan persahabatan. Pada konteks ini, Lazismu Kota Surakarta senantiasa membangun jiwa humanis yang ditunjukan dengan adanya kerja-kerja sosial yang dibutuhkan oleh masyarakat. Perihal tersebut dapat ditinjau dari berbagai programprogram filantropis yang telah dilakukan oleh Lazismu Kota Surakarta, yang salah satunya adalah pelaksanaan Qurban di daerah terpencil, terdalam, dan tertinggal (3T), yang dilakukan secara rutin pada perayaan Idul Adha.

Lazismu Kota Surakarta menemukan adanya ketidakadilan yang terjadi di daerah tersebut. Akses daerah yang sulit dilalui disebabkan adanya infrasturktur perhubungan yang tidak memadai dan berdampak pada ketidaksejahteraan pada daerah tersebut. Probelamatika tersebut mengakibatkan masyarakat sulit menerima haknya dalam mendapatkan daging qurban dan jarang untuk melaksanakan penyembelihan hewan qurban akibat dari faktor ekonomi masyarakat yang tidak mendukung. Hal inilah yang mendasari Lazismu Kota Surakarta untuk hadir kepada masyarakat melalui program Qurban di daerah 3T.

Agenda sosial yang dilaksanakan oleh Lazismu Kota Surakarta telah menujukan adanya kesadaran akal dan naruniah dalam menumbukan sikap kekeluargaan dan persahabatan sebagai manifestasi dari aktualisasi nilai keadilan sosial pada Pancasila. Hal ini selaras dengan penelitian Yudhistira (2016) yang menunjukan bahwa pengktualisasian nilai keadilan sosial pada Pancasila memerlukan adanya praktik nyata dalam rangka menciptakan kesejahteraaan rakyat sebagai dasar kekeluragaan seluruh bangsa Indonesia. Bilamana negara dan masyarakat dapat berperilaku adil maka persaudaran akan terjaga sebagaimana mestinya.

\section{Menjaga Keseimbangan antara Hak dan Kewajiban Asasi Manusia}

Salah satu hak warga negara Indonesia yang telah diatur dalam konstitusi adalah kesempatan untuk mendapatkan pendidikan yang layak. Orientasi dalam pemenuhan hak warga negara tersebut telah menjadi keharusan bagi negara untuk menyediakan pendidikan yang layak terhadap masyarakat (Shah dan Mieke, 2014). Namun hal tersebut belum ditemui secara menyeluruh mengingat masih banyak masyarakat yang kesulitan untuk 
mendapatkan pendidikan yang layak, baik secara formal, informal, maupun non formal.

Lazismu Kota Surakarta memiliki komitmen untuk hadir kepada masyarakat yang kesulitan dalam mendapatkan pendidikan. Hal tersebut dibuktikan melalui adanya program pendidikan yang diharapkan mampu membantu masyarakat yang ingin mendapatkan pendidikan yang layak. Program pendidikan yang diwujudkan oleh Lazismu Kota Surakarta adalah pemberian beasiswa dan Save our School.

Pemberian program beasiswa dan Save our School merupakan wujud nyata Lazismu Kota Surakarta yang memperdulikan hak masyarakat dalam mendapatkan pendidikan. Pendidikan merupakan hal penting yang harus diwujudkan sebagai bagian dari mencerdaskan kehidupan bangsa. Lazismu Kota Surakarta sebagai lembaga amal yang memungkinkan untuk melakukan pendistribusian materil yang didapatkan melaui dana infaq, sedekah, serta donasi, yang ditujukan untuk masyarakat miskin (Setiyowati, 2017).

Kegiatan yang dilakukan oleh Lazismu Kota Surakarta melalui program sosial pendidikan menunjukan adanya aktualisasi nilai keadilan sosial dalam Pancasila sebagai upaya menyeimbangkan hak dan kewajiban asasi manusia. Lazismu Kota Surakarta yang memiliki kemampuan materil, baik secara intelektual maupun moral, wajib menyediakan hak pendidikan bagi masyarakat dhuafa. Hal tersebut memperkuat penelitian Zabda (2016) yang menunjukan bahwa perlu adanya kecakapan intelektual dan moral dalam mengamalkan nilai-nilai filsafat Pancasila, khususnya pada nilai keadilan sosial.

Upaya Lazismu Kota Surakarta dalam menyediakan kebutuhan pendidikan bagi masyarakat juga selaras dengan penelitian Amal (2016) yang menunjukan bahwa advokat perlu menumbuhkan jiwa humanis sebagai bagian dari tanggung jawab moral kepada masyarakat dalam pelayanan bantuan hukum. Tidak semua masyarakat memilki kemampuan secara finansial untuk menggunakan pelayanan advokasi. Maka implemantasi ta'awun bagi advokat adalah memberikan bantuan hukum bagi masyarakat yang membutuhkan dalam rangka mencari titik keadilan.

\section{Memenuhi Kebutuhan dan Kepentingan Hidup Masyarakat Miskin}

Oientasi dari keadilan sosial adalah kesejahteraan masyarakat dalam rangka mewujudkan civil society yang cerdas, berkarakter, egaliter, etis dan 
terbuka. Dalam konteks ini, Vladimirovna dan Stupnikova (2015) menjelaskan bahwa keadilan menjadi unsur vital dengan mengoordinasikan sistem moral anggota masyarakat yang didasarkan atas ideologi dan agama. Hal ini dapat menjadi implikasi logis bilamana negara dan masyarakat mampu mengaktualisasikan nilai keadilan sosial dalam Pancasila secara optimal, maka kesejahteraan akan tercapai sebagai bagian dari kebutuhan dan kepentingan hidup masyarakat.

Lazismu Kota Surakarta hadir dalam agenda-agenda sosial yang telah dilaksanakan guna memenuhi kebutuhan dan kepentingan hidup masyarakat. Agenda sosial tersebut diwujudkan melalui program bantuan renovasi rumah bagi masyarakat fakir miskin, pelayanan kesehatan Surakarta Mobile Clinic di daerah pinggiran Kota Surakarta, serta dropping air bagi daerah terpencil yang mengalami kekeringan. Program bantuan yang telah dilaksanakan Lazismu Kota Surakarta dalam memenuhi kebutuhan dan kepentingan hidup masyarakat menujukan adanya problematika keadilan yang tidak terdistribusi secara menyeluruh kepada masyarakat miskin.

Berdasarkan fakta sosial di atas, problmatika keadilan dapat ditinjau dari struktur golongan masyarakat yang ada di Indonesia. Struktur sosial yang telah ada menurut John Rawls sebagaimana dikutip oleh Faiz (2009) merupakan pengklasifikasian atas kemampuan dan kebutuhan hidup masyarakat. Longo (2016), menjelaskan bahwa struktur sosial yang telah terklasifikasi dapat berpotensi adanya perselisihan dan ketidakstabilan yang menjadi ancaman umum dalam mewujudkan kesejahteraan sosial. Dampak dari hal tersebut ialah kemiskinan dan marjinalisasi yang menyangkut pada hajat dan kebutuhan hidup masyarakat.

Pengklasifikasian golongan masyarakat tersebut juga memiliki dampak lain terhadap adanya krisis hubungan masyarakat. Menurut Yefeng dkk (2014), bahwa krisis hubungan masyarakat dipengaruhi adanya persepsi terhadap kenyaman dan resiko hidup di dalam lingkungan sosialnya, yang meliputi ketahanan pangan, keamanan publik, kesehatan dan sejenisnya. Krisis hubungan masyarakat memiliki keterkaitan kuat terhadap adanya problematika keadilan sosial yang menyangkup pada aspek jaminan dan kebutuhan hidup, yang juga didasarkan atas persepsi masyarakat terhadap lingkungan sosialnya.

Solusi dalam menekan problematika keadilan sosial tersebut adalah adanya kebijaksanaan yang perlu dimunculkan dalam setiap golongan 
masyarakat itu sendiri. Upaya Lazismu Kota Surakarta dalam menanggulangi problematika keadilan sosial merupakan solusi konkret yang didasarkan atas kebijaksanaan dalam rangka menghasilkan kebaikan antar sesama. Hal tersebut mendukung penelitian Longo (2016) yang menunjukan bahwa perihal keadilan pangan dapat diwujudkan secara bijaksana melalui kepemilikan pribadi yang dapat menjadi sumber daya utama masyarakat dalam memenuhi kebutuhan panngannya, tanpa harus dimiliki secara bersamaan.

\section{Menumbuhkan Sifat dan Rasa Rendah Hati terhadap Sesama Manusia}

Sifat dan rendah hati merupakan unsur penting dalam mengatualisasikan nilai keadilan sosial pada Pancasila di dalam kehidupan bermasyarakat. Keadilan sosial merupakan tujuan dan cita-cita bangsa dalam menumbuhkan kepedulian antar sesama manusia. Oleh sebab itu, manusia sebagai makhluk eksistensialis perlu menunjukan perihal estetetis dan etis rangka menciptakan kebahagiaan bersama (Haryati, 2012).

Lazismu Kota Surakarta sebagai lembaga sosial memiliki programprogram yang berkaitan dengan keperluan hidup masyarakat, yang salah satunya adalah program Bangun Ekonomi Keluarga. Tujuan dari program tersebut adalah mengentaskan kemiskinan dengan proses pemberdayaan agar terciptanya kemandirian sosial melalui kewirausahaan. Hal tersebut dapat mendongkrak ekonomi masyarakat miskin menjadi sejahtera.

Program lain Lazismu Kota Surakarta dalam memenuhi keperluan masyarakat ialah pelayanan mobil ambulan gratis. Pelayanan mobil ambulan gratis tersebut ditujukan bagi masyarakat umum tanpa memandang latar belakang sosial masyarakat. Lazismu Kota Surakarta melalui porgram pelayanan mobil ambulan gratis telah menunjukan sebagai lembaga sosial yang berpihak kepada masyarakat yang memerlukan bantuan.

Perealisasian kedua program tersebut merupakan hasil dari pengelolaan dana umat melalui pengumpulan zakat, infak, dan sedekah. Dana umat yang telah dikelola kemudian digunakan sebagai modal utama untuk membantu masyarakat miskin dan yang membutuhkan pertolongan. Hal tersebut mengindikasikan adanya kerendahan hati terhadap sesama manusia sebagai unsur penting dalam mengaktualisasikan nilai keadilan sosial pada Pancasila yang telah ditunjukan oleh Lazismu Kota Surakarta melalui program-program sosialnya. 
CIVICS EDUCATION AND SOCIAL SCIENSE JOURNAL(CESSJ)

Volume 1 Nomor 2 Bulan Desember 2019

Perihal utama dalam merealisasikan substansi keadilan sosial adalah adanya prinsip moral dasar yang tebangun antar sesama manusia. Prinsip moral dasar menurut Surotsev dan Vasiliy (2015) adalah dengan menciptakan dan melestarikan kebaikan dalam rangka mencapai kebahagiaan bersama. Lazismu Kota Surakarta yang memiliki slogan transformatif "Memberi untuk Negeri” merupakan upaya proses kolektif dalam rangka mewujudkan negara Indonesia yang adil membangun masyarakat yang sejahtera melalui programprogram pemberdayaan sosial.

Terwujudnya negara yang adil dan masyarakat yang sejahtera merupakan tujuan Lazismu Kota Surakarta dalam mengabdikan diri kepada bangsa Indonesia. Hal tersebut selaras dengan penelitian Hidayat (2016) yang menunjukan bahwa tujuan Muhammadiyah adalah mewujudkan negara yang "baldatun thayyibatun wa rabbun ghafur", yang bermakna bahwa negara yang senantiasa menegakkan keadilan dan kesejahteraan rakyatnya. Muhammadiyah hadir dengan semangat dan misi Al-Quran disertai dengan etos kerja keras dan keteladanan bagi seluruh kader Muhammadiyah dalam rangka mewujudkan cita-cita negara ideal bagi NKRI.

Menurut Baidhawy dan Azaki (2017), Lazismu memerankan fungsi sebagai lembaga sosial alternatif bagi negara yang sedang mengalami disorientasi pada proses pemberdayaan masyarakat. Hal tersebut berimplikasi pada terpuruknya masyarakat miskin serta kesejahteraan yang merupakan tujuan utama keadilan sosial tidak terdistribusi kepada masyarakat secara menyeluruh. Etos kerja Lazismu Kota Surakarta didasarkan atas kedermawanan yang merupakan acuan tetap ajaran Islam yang transformatif dan tanggungjawab moral sebagai lembaga sosial yang hadir kepada masyarakat yang mengalami problematika sosial dan memerlukan bantuan. Upaya tersebut merupakan wujud konkret Lazismu Kota Surakarta yang turut berkontribusi kepada negara untuk hadir dalam menciptakan keadilan sosial. Lazismu Kota Surakata telah menunjukan sikap terbuka dan progressif serta memberi kebermanfatan kepada masyarakat yang ditunjukan melalui program-program yang telah dilaksanakan.

\section{KESIMPULAN}

Berdasarkan penelitian yang telah dilakukan, maka dapat disimpulkan bahwa aktualisasi nilai keadilan sosial dalam Pancasila melalui konsep ta'awun gerakan Muhammadiyah diwujudkan dengan adanya agenda-agenda sosial yang 
CIVICS EDUCATION AND SOCIAL SCIENSE JOURNAL(CESSJ)

Volume 1 Nomor 2 Bulan Desember 2019

dilaksanakan Lembaga Zakat dan Amal Lazismu Kota Surakarta. Persyarikatan Muhammadiyah melalui Lazismu Kota Surakarta dalam melaksanakan agenda sosial terbagi menjadi beberapa bidang yang diantaranya adalah: a. bidang pendidikan, melalui program pemberiaan Beasiswa Mentari bagi pelajar dan Beasiswa Sang Surya bagi mahasiswa, serta program Save our School; b. bidang sosial dakwah, melalui program bantuan renovasi rumah warga dan kegiatan Idul Adha di dareah 3T; c. bidang pemberdayaan ekonomi, melalui program BU EKA; d. bidang kesehatan dan kemanusiaan, melalui program Surakarta Mobile Clinic (SMC) dan pelayanan mobil ambulan gratis bagi masyarakat umum.

Semua kegiatan Lazismu Kota Surakarta didasarkan atas adanya problematika keadilan yang dialami oleh masyarakat. Problematika keadilan tersebut berakibat pada kemiskinan, marjinalisasi, dan ketidaksejahteraan masyarakat. Maka, konsep ta'awun yang secara harfiah mengandung unsur humanis untuk saling tolong menolong terhadap sesama manusia, telah dilaksanakan secara komprehensif oleh Lazismu Kota Surakarta melalui programprogram filantropis dan pemberdayaan dalam menanggulangi berbagai problematika keadilan yang dialami oleh masyarakat.

\section{DAFTAR PUSTAKA}

Amal, Ichlasul. 2016. "Implementasi Ta'awun dalam Praktik Bantuan Hukum oleh Advokat (Studi di Perhimpunan Advokat Indonesia Malang)". Skripsi S-1. Malang: Fakultas Syari'ah, Universitas Islam Negeri Maulana Malik Ibrahim Malang.

Baidhawy, Zakiyuddin dan Azaki Khoirudin. 2017. Etika Muhammadiyah dan Spirit Peradaban. Yogyakarta: Penerbit Suara Muhammadiyah.

Faiz, Pan Mohammad. 2009. "Teori Keadilan John Rawls". Jurnal Konstitusi, 6(1), 135-149.

Haryati, Tri Astuti. 2012. "Manusia dalam Perspektif Soren Kiekergaard dan Muhammad Iqbal”. Jurnal Penelitian, 9(1), 88-113.

Hidayat, Syamsul. 2016. "Pancasila sebagai Darul 'Ahdi wa al-Syahadah Wawasan dan Kontribusi Muhammadiyah bagi NKRI". Tajdida Jurnal Pemikiran dan Gerakan Muhammadiyah, 14(1), 12-17. 
CIVICS EDUCATION AND SOCIAL SCIENSE JOURNAL(CESSJ)

Volume 1 Nomor 2 Bulan Desember 2019

Jun, Chul Min. 2014. "The Paradigm Shift of Practical Theology and Theological Practice to Overcome Modernism and Postmodernism". Pasific Science Review. 16(1), 156-166.

Mu'ti, Abdul. 2016. “Apa itu Ta'awun?”. (https://www.republika.co.id/berita/ kolom/wacana/18/1 1/19/pif50z440-apa-itu-taawun). Diakses pada hari Jumat tanggal 19 April 2019 pukul 19.30 WIB.

Nashir, Haedar. 2016. "Muhammadiyah: Grakan Mondernisme Islam”. Tajdida Jurnal Pemikiran dan Gerakan Muhammadiyah, 14(1), 1-11.

Nashir, Haedar, Drajat T.K, Rachmad K.D.S, Bambang Setiyaji. 2019. "Islam In Indonesia: From Puritanism To Enlightening Religion in the Case of Muhammadiyah". Asia Life Sciences, 28(1), 1-15.

Lanur, Alex. 1995. Pancasila sebagai Ideologi Terbuka, Problema dan Tantangannya. Yogyakarta: Penerbit Kanisius.

Latif, Yudi. 2015. Negara Paripurna: Historisitas, Rasionalitas, Aktualisasi Pancasila. Jakarta: Pt Gramedia Pustaka Utama.

Latif, Yudi. 2018. "The Religiosity, Nationality,Sociality of Pancasila: Toward Pancasila Trought Soekarno's Way”. Indonesian Journal for Islamic Studies, 25(2), 207-244.

Longo, Patrizia. 2016. "Food Justice and Sustainability: A New Revolution”. Agriculture and Agricultural Science Procedia, 8, 31-36.

Roza, Abdul Gani J dan Dicki R M. 2016. Memahami dan Memaknai Pancasila sebagai Ideologi dan Dasar Negara. Jakarta: PT Gramedia Pustaka Utama.

Setiyowati, Arin. 2017. "Analisis Peranan Pengelolaan Dana Ziswaf oleh Civil Society dalam Pemberdayaan Ekonomi Umat (Studi Kasus Lazismu Surabaya)". Jurnal Masharif al-Syariah, 2(1), 1-32.

Shah, Ritesh dan Mieke T.A. 2014. Education and Social Change in Post-Conflict and Post-Disaster Aceh, Indonesia". International of Jounal Education Development, 19, 1-26.

Soeprapto, Sri. 1995. “Aktualisasi Nilai-Nilai Filsafat Pancasila Notonagoro". Jurnal Filsafat, 22, 30-37.

Surotvsev, Valery dan Vasily Syrov. 2015. "Outlooks of J. Rawls's Theory of Justice". Procedia - Social and Behavioral Sciences, 166, 176-181. 
CIVICS EDUCATION AND SOCIAL SCIENSE JOURNAL(CESSJ)

Volume 1 Nomor 2 Bulan Desember 2019

Viarstasiwi, Nino. 2013. "Holding on a Thin Rope: Muslim Papuan 'Communities as the Agent of Peace in Papua Conflict”. Procedia Environmental Sciences, 17, 860-869.

Vladimirovna, Syryamkina dan Stupnikova Olga Borisovna. 2015. "Prospects of the Civil Society Development in Post-Socialist Conditions". Procedia - Social and Behavioral Sceinces, 166, 189-193.

yefeng, Ma, Ying Gao, Hui Zhang, Yi Liu, dan Changqin Lu. 2014. "Perception on Safety and Justice Related to Social Environment in Mainland China: a Survey". Procedia Engineering, 78, 292-298.

Yudhistira. 2016. "Aktualisasi dan Implementasi Nilai-Nilai Pancasila dalam Menumbuh Kembangkan Karakter Bangsa". Jurnal Hukum Unes, 2(1), 421-436.

Zabda, Sutan Syahrir. 2016. “Aktualisasi Nilai-Nilai Pancasila sebagai Dasar Falsafah Negara dan Implementasinya dalam Pembangunan Karakter Bangsa”. Jurnal Pendidikan Ilmu Sosial, 26(2), 106-114. 